\title{
CHANGE OF SURFACE COLOUR PARAMETERS DURING STORAGE OF PAPRIKA (Capsicum annuUm L.)
}

\author{
Miona M. Belović*, Jasna S. Mastilović, Žarko S. Kevrešan \\ University of Novi Sad, Institute of Food Technology, Bulevar cara Lazara 1, 21000 Novi Sad, Serbia
}

\author{
*Corresponding author: \\ Phone: +381214853779 \\ E-mail address: miona.belovic@fins.uns.ac.rs
}

\begin{abstract}
The change of paprika surface colour during three years of storage was monitored by measuring $\mathrm{CIEL}^{*} \mathrm{a}^{*} \mathrm{~b}^{*}$ colour parameters once a year. Ten commercial and three branded paprika samples, originating from Hungary, Austria and Serbia, were stored in original packaging at ambient temperature in dark during the storage period. The colour of paprika powder was measured by Chroma Meter CR-400 (Konica Minolta, Japan), using attachment for granular materials CR-A50. Directly measured colour parameters were CIE $\mathrm{L}^{*}$ (lightness), $\mathrm{a}^{*}\left(+\mathrm{a}^{*}=\right.$ redness, $-\mathrm{a}^{*}=$ greenness $), \mathrm{b}^{*}$ $\left(+b^{*}=\right.$ yellowness, $-b^{*}=$ blueness $)$ and dominant wavelength $(D W L)$, while derived colour parameters were chroma $\left(\mathrm{C}^{*}\right)$, hue angle $\left(\mathrm{h}^{\circ}\right)$, and total colour change $(\Delta \mathrm{E})$. Paprika samples had similar granulation, and therefore it was concluded that it did not influence the colour reflection. The change of reflected colour of paprika powder during storage can be characterized by increase of CIE $L^{*}$ and $b^{*}$ colour values and decrease of $a^{*}$ colour value. Therefore, chroma values remained almost unchanged, while hue angle showed shift in spectrum from red-orange to orange-yellow, similarly to dominant wavelength. The paprika samples changed their colour most rapidly during the first year of storage, except the branded paprika from Serbia. Commercial paprika samples from Serbian market changed their colour more rapidly comparing to other investigated samples.
\end{abstract}

Key words: paprika, colour, storage

\section{INTRODUCTION}

Paprika is the powder prepared from red pepper fruits (Capsicum annuum L.) used as a spice to give colour, flavour and pungency to various dishes. Red colour intensity is considered as the main quality attribute of paprika, since it influences both consumer acceptance and commercial value (Gomez et al. 1998, Nieto-Sandoval et al. 1999; Ergüneş and Tarhan 2006). More pronounced differences between the paprika samples obtained by measuring of colorimetric values are supposed to be the consequence of different content of browning pigments (Kim et al. 2006). Paprika colour degradation during processing and storage is the major problem in its pro- duction and trade but also during prolonged storage of spice paprika in the households (Biacs et al. 1992). It is mainly a consequence of carotenoids degradation and non-enzymatic browning reactions (Topuz 2008). These reactions are accelerated by higher temperatures and water activities, light and molecular oxygen (Ergüneş and Tarhan 2006; Topuz 2008).

There are several methods for paprika colour evaluation, based on the measurement of surface colour, extraction of pigments, and profiling of carotenoids (Mínguez-Mosquera and Hornero-Méndez 1994; Deli et al. 1996; Kevrešan et al. 
2009; Kevrešan et al. 2013). The official analytical method of ASTA (American Spice Trade Association) (ASTA Analytical Method 20.1, 1986) is the reference analytical method for colour measurement in the international trade, but it only indicates the content of pigments and the colour hue (Mínguez-Mosquera and Pérez-Gálvez 1998; Kim et al. 2008). However, tristimulus colourimetry presents quick, easy and non-destructive method, allowing more precise classification and differentiation of the samples by their external colour than the ASTA method (Gomez et al. 1998; Kim et al. 2006).

There have been several studies that monitored changes of different colour parameters of pepper powder during storage (Osuna-Garcia et al. 1997; Osuna Garcia and Wall 1998; Tepić and Vujičić 2004; Topuz et al. 2009). However, none of them has been carried out in a period longer than 4 months. There are studies where change of ASTA values was monitored during 1 year period (Chatterjee et al. 1998; Pérez-Gálvez et al. 2009). The declared expiration date of most paprika powders is at least a year, while their utilization in the households often lasts much longer. Shelf life was defined as $50 \%$ loss of total carotenoid content (half-life) in the study of Pérez-Gálvez et al. (2009), and it was calculated using first order kinetic model to be about 5 years. In the market, paprika originating from different places and branded by different producers can be found along with paprika powders with protected geographic identifications. However, the issue of difference in colour change and its stability during the common storage period among paprika powders with different origin has been investigated only in a shorter period.

Based on the facts mentioned above, the aim of the research was to monitor the changes of paprika colour during three years of storage by measuring of CIEL ${ }^{*}{ }^{*} b^{*}$ colour parameters once a year.

\section{MATERIALS AND METHODS}

\section{Material and storage conditions}

Thirteen commercial samples of ground red pepper (paprika) were bought at the market. All samples originated from pep- per produced in southeast Europe, namely the Pannonian plain, area which is well recognized for high quality paprika production. Four commercial samples originated from Serbia, three from Hungary and three from Austria. Additional three samples represent brand paprika from Serbia. In each group one pungent sample was included, while the others were sweet. The surface colour of the samples was measured before storage and then once a year, during the following three years. Paprika samples were stored in original packaging (closed bags) at ambient temperature $\left(21 \pm 5^{\circ} \mathrm{C}\right)$ in dark during the entire storage period.

\section{Colour measurement}

The colour of paprika powder was directly measured with Chroma Meter CR-400 (Konica Minolta, Japan), using attachment for granular materials CR-A50. CIE $L^{*}$ (lightness), $\mathrm{CIE} \mathrm{a}^{*}\left(+\mathrm{a}^{*}=\right.$ redness, $-\mathrm{a}^{*}=$ greenness), CIE $b^{*}\left(+b^{*}=\right.$ yellowness, $-b^{*}$ = blueness), $\mathrm{C}^{*}$ (chroma), $\mathrm{h}^{\circ}$ (hue angle), and DWL (dominant wavelength, $\mathrm{nm}$ ) were read using $a D_{65}$ light source and the observer angle of $2^{\circ}$. The tristimulus values of CIE $L^{*} a^{*} b^{*}$ readings were calibrated against a standard white plate $(Y=84.8 ; \quad X=0.3199 ; \quad y=0.3377)$. Each sample was measured in three replicates, and the values were presented as mean \pm standard deviation.

Derived colour parameters, hue angle and chroma were calculated using the following equations (Topuz et al. 2009):

$$
\begin{aligned}
& h^{\circ}=\arctan \left(\frac{b}{a}\right) \\
& C=\sqrt{a^{2}+b^{2}}
\end{aligned}
$$

The hue angle value represents the position of determined colour in the colour wheel, with red-purple at an angle of $0^{\circ}$, yellow at $90^{\circ}$, bluish-green at $180^{\circ}$ and blue at $270^{\circ}$. The chroma value represents colour saturation of the samples, with high values representing vivid colour (Topuz et al. 2009; Tepić et al. 2010).

Total colour change $(\Delta \mathrm{E})$ between samples stored for a different period was calculated according to the following formula (Ergüneş and Tarhan 2006): 


$$
\Delta E=\sqrt{\left(L_{2}^{*}-L_{1}^{*}\right)^{2}+\left(a_{2}^{*}-a_{1}^{*}\right)^{2}+\left(b^{*}{ }_{2}-b_{1}^{*}\right)^{2}}
$$

The mean particle diameter was measured by sieving the previously weighted sample through eight sieves, using Bühler (Switzerland) rotational sieving machine. Sieve openings were in the range from $500 \mu \mathrm{m}$ to $100 \mu \mathrm{m}$, and mass of paprika powder retained on each sieve was measured. The mean diameter of particles was calculated as follows (Tepić et al. 2010):

$\frac{100}{d}=\sum\left(\frac{m_{i}}{d_{i}}\right)$

where: $m_{i^{-}}$mass percent of fraction $i ; d_{i^{-}}$ mean diameter of the $i$ fraction.

\section{RESULTS AND DISCUSSION}

\section{Particle mean diameter}

Particle mean diameters of examined paprika samples are presented in Table 1. It is known that particle diameter of paprika powders influences the reflected colour (Tepić et al. 2010). Since the mean diameter of all samples was in quite narrow range from $149 \mu \mathrm{m}$ to $206 \mu \mathrm{m}$, colour variation cannot be attributed to the differences in particle size.

\section{Change of colour parameters during storage}

Change of colour parameters during storage is presented in Figure 1. All paprika samples with the increased storage time under applied storage conditions became lighter (higher $L^{*}$ values). The most ex- pressed lightness increase was observed in commercial samples from Serbia, while for branded paprika samples from Serbia increase of lightness was much slower but it continued during the entire storage period. The most expressed lightness change in samples from Hungary and Austria occurred during the first year while in the later period it changed only slightly. Contrary to our findings, Topuz et al. (2009) reported a trend of lightness decrease in the storage period of 3 months. During the storage period, the intensity of red colour ( $a^{*}$ values) decreased, with the most rapid decrease observed for the commercial samples from Serbia (Figure 1). Considering the intensity of yellow colour ( $b^{*}$ values), commercial paprika samples from Serbia, as well from Hungary and Austria, showed increase with storage time, while for branded paprika from Serbia the changes of yellow tone intensity were almost not noticed. These trends in red and yellow colour change led to relatively constant $\mathrm{C}^{*}$ values during storage (Table 2). In the study of Topuz et al. (2009), decrease of $a^{*}$ values was also noticed, as well as decrease in $b^{*}$ and $C^{*}$ values which is in opposition to our findings. However, different trends in colour changes refer to different storage periods and different storage conditions and thus cannot be compared directly. Starting values for the hue angle $\left(h^{\circ}\right)$ were around $45^{\circ}$, which represents red-orange area on the colour wheel (Table 3). These values are usual for paprika samples (Tepić et al. 2010).

Table 1.

Paprika sample origin, pungency and particle mean diameter

\begin{tabular}{lccc}
\hline Paprika origin & & Pungency & Mean diameter $(\boldsymbol{\mu m})$ \\
\hline \multirow{3}{*}{ Hungary } & \multirow{2}{*}{ commercial } & pungent & 169 \\
& & sweet & 183 \\
& & sweet & 149 \\
\hline \multirow{3}{*}{ Austria } & \multirow{2}{*}{ commercial } & pungent & 190 \\
& & sweet & 189 \\
& & sweet & 187 \\
\hline \multirow{3}{*}{ Serbia } & \multirow{2}{*}{ commercial } & pungent & 204 \\
& & sweet & 173 \\
& & sweet & 169 \\
& \multirow{2}{*}{ branded } & sweet & 172 \\
\hline & & pungent & 189 \\
& & sweet & 178 \\
& & sweet & 206 \\
\hline
\end{tabular}




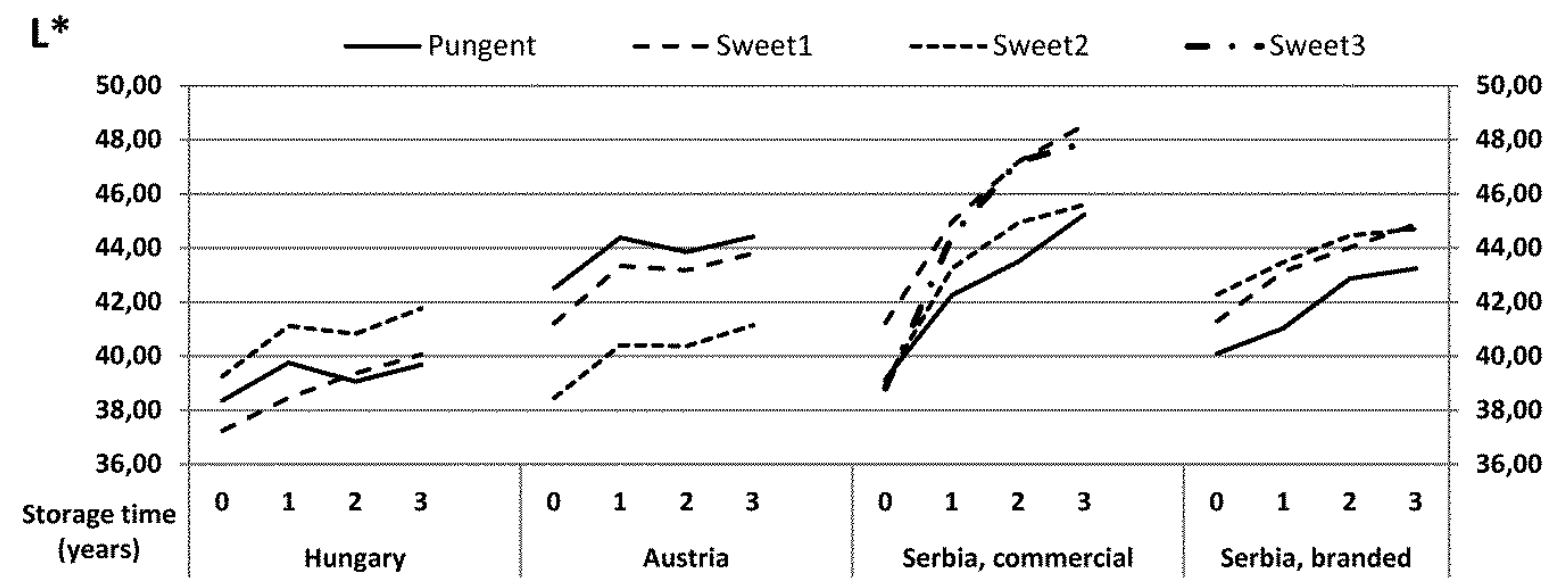

$a^{*}$
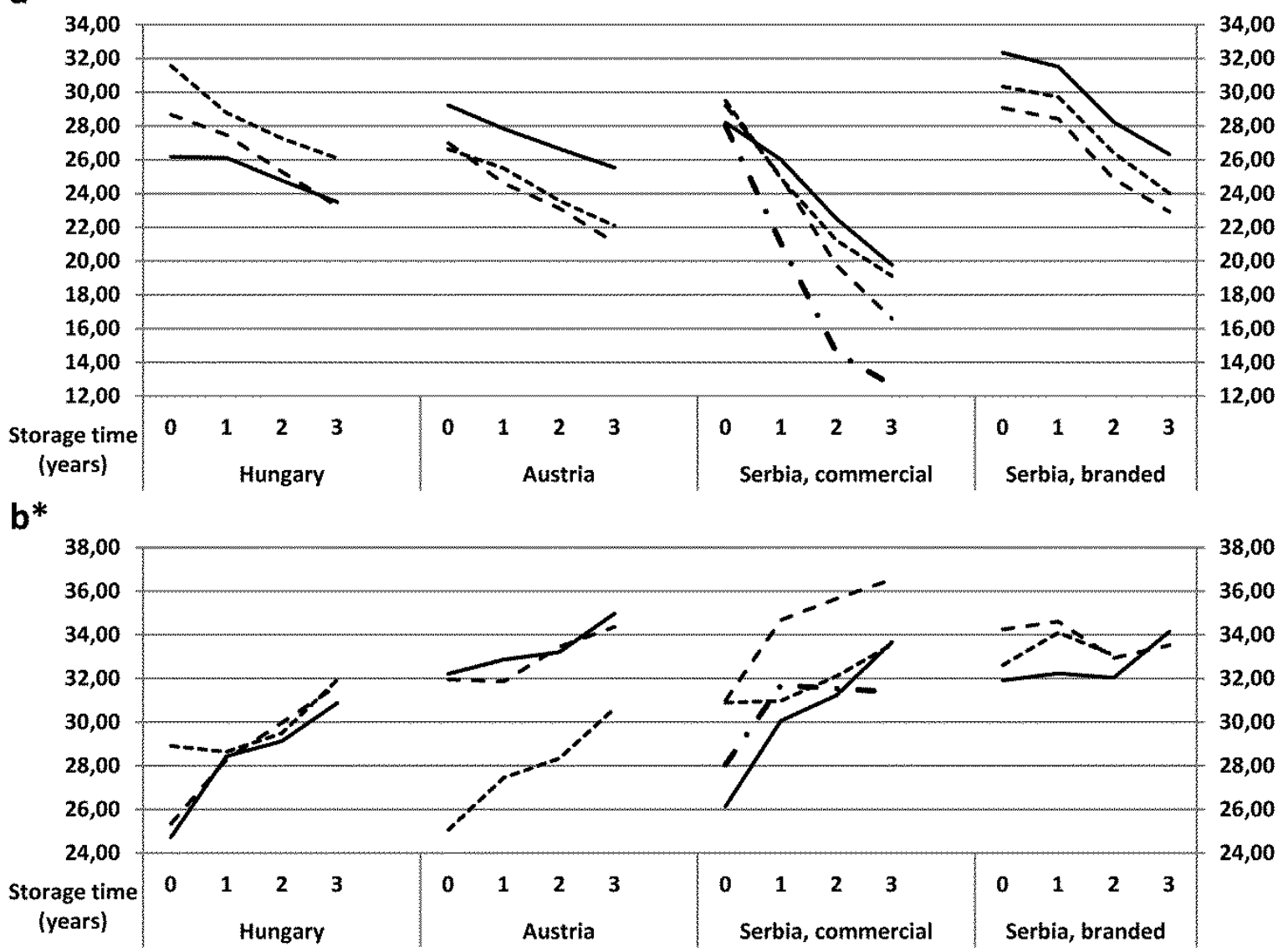

Figure 1. Change of colour parameters of paprika during storage

Final hue angle values after three years for the samples from Hungarian and Austrian market, as well as for the branded samples from Serbia were at the level of around $55^{\circ}$ indicating change of colour from red-orange to more expressed orange tone. For commercial samples from Serbian market hue angle values increased up to $70^{\circ}$, to the range of orange-yellow colour. Trend of hue angle increase during storage period of four months was reported by few authors (Osuna-Garcia et al. 1997; Osuna-Garcia and Wall 1998; Tepić and Vujičić 2004), while in experiment conducted by Topuz et al. (2009) that lasted for 3 months no significant changes of hue angle were recorded. Change of dominant wavelength expressed trend of decrease similar to the above mentioned trend of hue angle increase (Table 4), which was the consequence of the visible transition of paprika colour from red-orange to orange-yellow hues. Total colour change $(\Delta \mathrm{E})$, which indicates 
Table 2.

Change of chroma values of paprika during storage

\begin{tabular}{llcccc}
\hline \multirow{2}{*}{ Sample } & & \multicolumn{4}{c}{ Storage time (years) } \\
\cline { 3 - 5 } & & $\mathbf{0}$ & $\mathbf{1}$ & $\mathbf{2}$ & $\mathbf{3}$ \\
\hline \multirow{2}{*}{ Hungary } & pungent & $36.0 \pm 0.84$ & $38.6 \pm 0.74$ & $38.2 \pm 0.45$ & $38.8 \pm 0.30$ \\
commercial & sweet & $38.3 \pm 0.81$ & $39.4 \pm 0.39$ & $39.2 \pm 0.07$ & $39.3 \pm 0.07$ \\
& sweet & $42.8 \pm 0.28$ & $40.6 \pm 0.39$ & $40.2 \pm 0.16$ & $41.2 \pm 0.22$ \\
\hline \multirow{2}{*}{ Austria } & pungent & $43.5 \pm 0.25$ & $43.1 \pm 0.31$ & $42.6 \pm 0.37$ & $43.3 \pm 0.52$ \\
commercial & sweet & $41.8 \pm 1.02$ & $40.3 \pm 0.97$ & $40.7 \pm 0.73$ & $40.3 \pm 0.62$ \\
& sweet & $36.6 \pm 1.13$ & $37.5 \pm 0.53$ & $36.9 \pm 0.42$ & $37.8 \pm 0.35$ \\
\hline \multirow{2}{*}{ Serbia } & pungent & $38.5 \pm 0.52$ & $39.8 \pm 0.27$ & $38.5 \pm 0.17$ & $39.0 \pm 0.57$ \\
commercial & sweet & $42.6 \pm 0.53$ & $42.7 \pm 0.14$ & $40.8 \pm 0.31$ & $40.1 \pm 0.24$ \\
& sweet & $42.7 \pm 0.57$ & $39.7 \pm 0.35$ & $38.5 \pm 0.38$ & $38.6 \pm 0.31$ \\
& sweet & $39.7 \pm 0.68$ & $38.0 \pm 0.49$ & $34.7 \pm 0.18$ & $33.8 \pm 0.10$ \\
\hline \multirow{2}{*}{ Serbia branded } & pungent & $45.4 \pm 0.64$ & $45.1 \pm 0.83$ & $42.7 \pm 0.40$ & $43.1 \pm 0.24$ \\
& sweet & $44.9 \pm 0.85$ & $44.8 \pm 0.46$ & $41.3 \pm 0.68$ & $40.6 \pm 0.19$ \\
\hline
\end{tabular}

Results are given as mean \pm standard deviation $(n=3)$

Table 3.

Change of hue angle values of paprika during storage

\begin{tabular}{llcccc}
\hline \multirow{2}{*}{ Sample } & & \multicolumn{4}{c}{ Storage time (years) } \\
\cline { 3 - 5 } & & $\mathbf{0}$ & $\mathbf{1}$ & $\mathbf{2}$ & $\mathbf{3}$ \\
\hline \multirow{2}{*}{ Hungary } & pungent & $43.4 \pm 0.32$ & $47.4 \pm 0.19$ & $49.7 \pm 0.20$ & $52.7 \pm 0.43$ \\
commercial & sweet & $41.5 \pm 0.55$ & $45.8 \pm 0.19$ & $49.9 \pm 0.18$ & $53.7 \pm 0.11$ \\
& sweet & $42.5 \pm 0.16$ & $44.9 \pm 0.18$ & $47.3 \pm 0.12$ & $50.8 \pm 0.34$ \\
\hline \multirow{2}{*}{ Austria } & pungent & $47.8 \pm 0.26$ & $49.7 \pm 0.12$ & $51.3 \pm 0.21$ & $53.9 \pm 0.18$ \\
commercial & sweet & $49.8 \pm 0.36$ & $52.3 \pm 0.52$ & $55.3 \pm 0.32$ & $58.5 \pm 0.11$ \\
& sweet & $43.3 \pm 0.94$ & $47.1 \pm 0.48$ & $50.2 \pm 0.38$ & $54.2 \pm 0.34$ \\
\hline \multirow{2}{*}{ Serbia } & pungent & $42.8 \pm 0.25$ & $49.1 \pm 0.19$ & $54.2 \pm 0.12$ & $59.6 \pm 0.38$ \\
commercial & sweet & $46.7 \pm 0.28$ & $54.2 \pm 0.18$ & $61.0 \pm 0.35$ & $65.6 \pm 0.11$ \\
& sweet & $46.3 \pm 0.41$ & $51.2 \pm 0.51$ & $56.5 \pm 0.41$ & $60.3 \pm 0.30$ \\
& sweet & $45.0 \pm 0.35$ & $56.4 \pm 0.21$ & $65.2 \pm 0.26$ & $68.0 \pm 0.16$ \\
\multirow{2}{*}{ Serbia branded } & pungent & $44.6 \pm 0.46$ & $45.6 \pm 0.22$ & $48.6 \pm 0.46$ & $52.4 \pm 0.06$ \\
& sweet & $49.7 \pm 0.28$ & $50.6 \pm 0.15$ & $52.9 \pm 0.42$ & $55.6 \pm 0.39$ \\
\hline
\end{tabular}

Results are given as mean \pm standard deviation $(n=3)$

Table 4.

Change of dominant wavelength of paprika during storage

\begin{tabular}{llcccc}
\hline \multirow{2}{*}{ Sample } & & \multicolumn{4}{c}{ Storage time (years) } \\
\cline { 3 - 5 } & & $\mathbf{0}$ & $\mathbf{1}$ & $\mathbf{2}$ & $\mathbf{3}$ \\
\hline \multirow{2}{*}{ Hungary } & pungent & $596 \pm 0.21$ & $594 \pm 0.06$ & $593 \pm 0.04$ & $591 \pm 0.20$ \\
commercial & sweet & $598 \pm 0.17$ & $595 \pm 0.04$ & $593 \pm 0.08$ & $591 \pm 0.09$ \\
& sweet & $598 \pm 0.11$ & $595 \pm 0.15$ & $594 \pm 0.07$ & $592 \pm 0.16$ \\
\hline \multirow{2}{*}{ Austria } & pungent & $594 \pm 0.13$ & $593 \pm 0.08$ & $592 \pm 0.07$ & $591 \pm 0.12$ \\
commercial & sweet & $593 \pm 0.10$ & $591 \pm 0.17$ & $590 \pm 0.09$ & $589 \pm 0.02$ \\
& sweet & $596 \pm 0.35$ & $594 \pm 0.21$ & $592 \pm 0.17$ & $590 \pm 0.15$ \\
\hline \multirow{2}{*}{ Serbia } & pungent & $596 \pm 0.12$ & $593 \pm 0.05$ & $590 \pm 0.09$ & $588 \pm 0.18$ \\
commercial & sweet & $595 \pm 0.09$ & $591 \pm 0.06$ & $587 \pm 0.15$ & $585 \pm 0.07$ \\
& sweet & $595 \pm 0.16$ & $592 \pm 0.24$ & $589 \pm 0.13$ & $588 \pm 0.11$ \\
& sweet & $595 \pm 0.14$ & $589 \pm 0.09$ & $585 \pm 0.12$ & $584 \pm 0.06$ \\
\hline \multirow{2}{*}{ Serbia branded } & pungent & $597 \pm 0.20$ & $596 \pm 0.12$ & $594 \pm 0.22$ & $592 \pm 0.04$ \\
& sweet & $594 \pm 0.14$ & $593 \pm 0.07$ & $591 \pm 0.09$ & $590 \pm 0.14$ \\
& sweet & $595 \pm 0.13$ & $594 \pm 0.07$ & $592 \pm 0.11$ & $590 \pm 0.12$ \\
\hline
\end{tabular}

Results are given as mean \pm standard deviation $(n=3)$

the degree of colour difference between two samples, was calculated between years of storage for all samples, and $\Delta \mathrm{E}$ values after each year of storage were presented in stacked column plot (Figure 2) in order to enable comparison among 
storage periods and paprika samples origin. Degree of colour difference between two samples based on total colour change values can be interpreted in the following way: $\Delta E$ in the range of $0-0.5$ indicates an imperceptible difference in colour, 0.5-1.5 a slight difference, 1.5-3.0 a just noticeable difference, 3.0-6.0 a marked difference, 6.0-12.0 an extremely marked difference, and above 12.0 a colour of a different shade (Kim et al. 2008). For all samples except branded paprika powders from Serbian market, the highest total colour change occurred in the first storage year. For paprika samples from Austrian market, the colour difference values after the first year of storage were below 3 . For the paprika powder samples from Hungary colour difference after the first year was up to 4, while for the commercial samples from Serbian market it was around 6 and above. For the branded paprika powders from Serbian market colour difference in the first storage year was up to 2 and the main, although not very intensive $(\Delta \mathrm{E}$ from 2 to 3 ) colour changes occurred during the second storage year. After three years of storage, the commercial samples from Serbian market were characterized by colour difference above 12 in comparison to initial colour indicating that the powders achieved the colour of different shade. For the other paprika powder samples, colour difference in three years period was almost half of that pointing out at much more stable colour during the long period. The change of colour parameters of the paprika powders during storage could be explained by the oxidative degradation of carotenoids, which are prone to oxidation because of conjugated double bonds in their structure (Osuna-Garcia et al. 1997; Topuz and Ozdemir 2003; Kim et al. 2008). These reactions are accelerated by the high surface area of the paprika particles, and strongly depend on the drying conditions during industrial processing (Daood et al. 2006). Another possible cause of these colour changes is the fact that all paprika found in Serbian market (both commercial and branded samples) pass the process of sterilization (in the final stage of preparation) in order to keep the total count of microorganisms at acceptable level. This type of sample (sterilized paprika) is more prone to colour change in comparison to non-treated (nonsterilized) paprika, and research on this problem was published by Vračar et al. (2007).

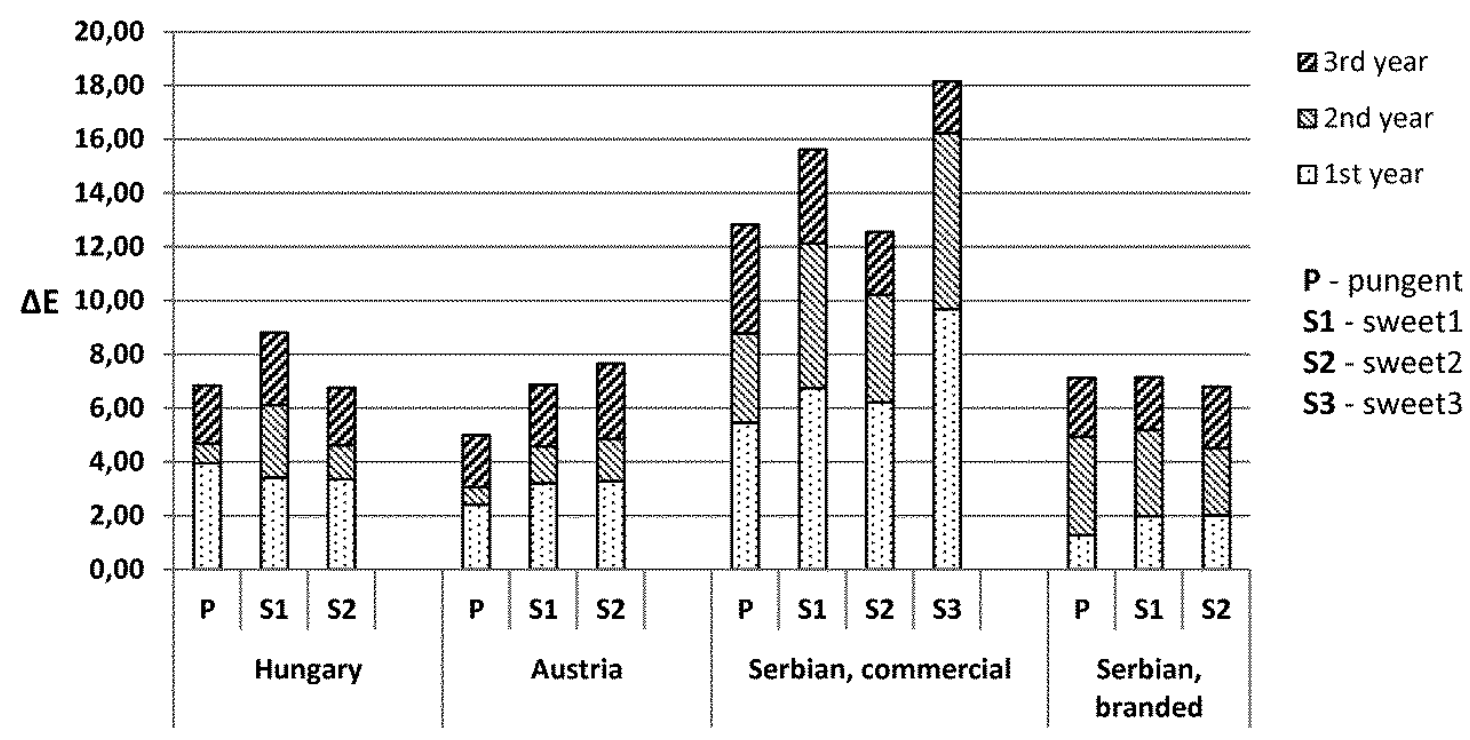

Figure 2. Total colour change in each year of storage for paprika samples 


\section{CONCLUSION}

From the presented results, it can be concluded that change of reflected colour of paprika powder during three years storage period is characterized by increase of lightness $\left(\mathrm{CIE} \mathrm{L}^{*}\right)$, decrease of red colour intensity (CIE $a^{*}$ value) and increase of yellow colour intensity (CIE $b^{*}$ value), while the hue angle showed shift from redorange to orange-yellow. Dominant wavelength (DWL) decreased with the same trend, also indicating change from red to yellow hues in reflected spectrum while the chroma $\left(\mathrm{C}^{*}\right)$ remained almost unchanged.

The colour changed most rapidly during the first year of storage except in the case of the branded paprika from Serbia which had the most stable colour during the first storage year. In the second and especially in the third year, the colour change decreased.

Regarding differences between the paprika samples of different origin, commercial paprika samples bought in Serbia changed their colour more rapidly comparing to the other samples, with the highest total colour change in the end of storage period. On the contrary, Serbian brand paprika showed least change after the first year of storage.

\section{ACKNOWLEDGEMENTS}

This paper is a result of the researches within the project III 46001, financed by the Ministry of Education, Science, and Technological Development, Republic of Serbia.

\section{REFERENCES}

1. Biacs, P. A., Czinkotai, B., Hoschke, A. 1992. Factors Affecting Stability of Colored Substances in Paprika Powders. Journal of Agricultural and Food Chemistry, 40 (3), 363-367.

2. Chatterjee, S., Padwal-Desai, S. R., Thomas, P. 1998. Effect of $y$-irradiation on the colour power of turmeric (Curcuma longa) and red chillies (Capsicum annum) during storage. Food Research International, 31 (9), 625-628.

3. Daood, H. G., Kapitány, J. Biacs, P., Albrecht, K. 2006. Drying temperature, endogenous antioxidants and capsaicinoids affect carotenoid stability in paprika (red pepper spice).
Journal of the Science of Food and Agriculture, $86,2450-2457$.

4. Deli, J., Matus, Z., Tóth, G. 1996. Carotenoid Composition in the Fruits of Capsicum annuum Cv. Szentesi Kosszarvú during Ripening. Journal of Agricultural and Food Chemistry, 44 (3), 711-716.

5. Ergüneş, G., Tarhan, S. 2006. Color retention of red peppers by chemical pretreatments during greenhouse and open sun drying. Journal of Food Engineering, 76, 446-452.

6. Gomez, R., Pardo, J. E., Navarro, F., Varon, R. 1998. Colour Differences in Paprika Pepper Varieties (Capsicum annuum L) Cultivated in a Greenhouse and in the Open Air. Journal of the Science of Food and Agriculture, 77, 268-272.

7. Kevrešan, Ž., Mandić, A., Kuhajda, K., Sakač, M. 2009. Carotenoid content in fresh and dry pepper Capsicum annuum L. fruits for paprika production. Food Processing, Quality and Safety, 36 (1-2), 21-27.

8.

A., Torbica

A. 2013. Effect of Different Ripening Conditions on Pigments of Pepper for Paprika Production at Green Stage of Maturity. Journal of Agricultural and Food Chemistry, 61, 9125-9130.

9. Kim, S., Ha, T. Y., Park, J. 2008. Characteristics of pigment composition and colour value by the difference of harvesting times in Korean red pepper varieties (Capsicum annuum, L.). International Journal of Food Science and Technology, 43, 915-920.

10. Kim, S., Lee, K. W., Park, J., Lee, H. J., Hwang, I. K. 2006. Effect of drying in antioxidant activity and changes of ascorbic acid and colour by different drying and storage in Korean red pepper (Capsicum annuum, L.). International Journal of Food Science and Technology, 41 (Supplement 1), 90-95.

11. Mínguez-Mosquera, M. I., Hornero-Méndez, D. 1994. Comparative study of the effect of paprika processing on the carotenoids in peppers (Capsicum annuum L.) of the Bola and Agridulce varieties. Journal of Agricultural and Food Chemistry, 42 (7), 1555-1560.

12. Mínguez-Mosquera, M. I., Pérez-Gálvez, A. 1998. Color Quality in Paprika Oleoresins. Journal of Agricultural and Food Chemistry, 46 (12), 5124-5127.

13. Nieto-Sandoval, J. M., Fernández-López, J. A., Almela, L., Muñoz, J. A. 1999. Dependence between Apparent Color and Extractable Color in Paprika. Color Research and Application, 24 (2), 93-97.

14. Osuna-Garcia, J. A., Wall, M. M. 1998. Prestorage moisture content affects color loss of ground paprika (Capsicum annuurn L.) under storage. Journal of Food Quality, 21, 251-259.

15. Osuna-Garcia, J. A., Wall, M. M., Waddell, C. A. 1997. Natural Antioxidants for Preventing Color Loss in Stored Paprika. Journal of Food Science, 62 (5), 1017-1021. 
16. Pérez-Gálvez, A., Hornero-Méndez, D., Mínguez-Mosquera, M. I. 2009. Stability of Paprika without Supplementary Antioxidants during Storage under Industrial Controlled Conditions. Journal of Agricultural and Food Chemistry, 57 (11), 4718-4723.

17. Tepić, A. N., Šumić, Z. M., Vukan, M. B. 2010. Influence of particle diameter on the colour of ground pepper (Capsicum annuum L.). Acta Periodica Technologica, 41, 87-93.

18. Tepić, A. N., Vujičić, B. L. 2004. Colour change in pepper (Capsicum annuum) during storage. Acta Periodica Technologica, 35, 59-64.

19. Topuz, A. 2008. A novel approach for color degradation kinetics of paprika as a function of water activity. LWT - Food Science and Technology, 41, 1672-1677.

20. Topuz, A., Feng, H., Kushad, M. 2009. The effect of drying method and storage on color characteristics of paprika. LWT - Food Science and Technology, 42, 1667-1673.

21. Topuz, A., Ozdemir, F. 2003. Influences of $y$ Irradiation and Storage on the Carotenoids of Sun-Dried and Dehydrated Paprika. Journal of Agricultural and Food Chemistry, 51 (17), 49724977.

22. Vračar, Lj. O., Tepić, A. N., Vujičić, B. L., Solaja, S. (2007). Influence of the heat treatment on the colour of ground pepper (Capsicum annuum). Acta Periodica Technologica, 38, 53-58

\title{
ПРОМЕНА ПОВРШИНСКЕ БОЈЕ ПАПРИКЕ (Capsicum annuUm L.) ТОКОМ СКЛАДИШТЕЊА
}

\author{
Миона М. Беловић*, Јасна С. Мастиловић, Жарко С. Кеврешан \\ Универзитет у Новом Саду, Научни институт за прехрамбене технологије у Новом Саду, \\ Булевар цара Лазара бр. 1, 21000 Нови Сад, Србија
}

Сажетак: Промена површинске боје паприке праћена је током три године складиштења, мерењем CIEL*a*b* параметара боје једном годишње. Десет комерцијалних и три брендирана узорка паприке, пореклом из Мађарске, Аустрије и Србије, чувани су у оригиналном паковању на собној температури у мраку током времена складиштења. Боја млевене зачинске паприке измерена је применом Chroma Meter-a CR-400 (Konica Minolta, Јaпан), са наставком за гранулиране материје CR-A50. Очитани параметри боје су CIE L* (светлоћа), a* $\left(+a^{*}=\right.$ црвени тон, $-a^{*}=$ зелени тон $), b^{*}\left(+b^{*}=\right.$ жути тон, $-b^{*}=$ плави тон $)$ и доминантна таласна дужина (DWL), а изведени параметри засићеност боје $\left(C^{*}\right)$, нијанса $\left(h^{\circ}\right)$ и укупна промена боје $(\Delta \mathrm{E})$. Узорци паприке били су сличне гранулације, на основу чега је закључено да она није утицала на рефлексију боје. Промена површинске боје током складиштења је окарактерисана порастом CIE $\mathrm{L}^{*}$ and $\mathrm{b}^{*}$ вредности и смањењем $\mathrm{a}^{*}$ вредности параметара боје. Стога је засићеност боје остала скоро непромењена, док је нијанса показала помак у спектру од црвено-наранџасте ка наранџасто-жутој, слично као и доминанатна таласна дужина. Боја узорака паприке најбрже се мењала током прве године складиштења, осим у случају брендиране паприке из Србије. Комерцијални узорци паприке са српског тржишта су променили боју брже у односу на друге испитиване узорке.

Кључне речи: паприка, боја, складиштење 